\title{
Effect of Micro-Teaching Method Supported by E-Learning Platforms in Enriching Pre-service Mathematics Teachers' Teaching Practice s And Improve Self-efficacy
}

\author{
Dr. Marwa Nabil El-ahwal \\ Lecturer at Faculty of Education, Tanta University, EGYPT)
}

\begin{abstract}
The objective of the current research is Effect of Micro-Teaching Method Supported by E-Learning Platforms in Enriching Pre-Service Mathematics Teachers' Teaching practice and Improving Self-efficacy, and the research sample consisted of (60) students from the second year students, who were divided into two groups, Designing research tools (a note card for Teaching practice ), and a scale (for self-efficacy), and the researcher found that there are differences between the performance of students members of the experimental group in the note card of Teaching practice in favor post application, as well as the existence of differences between the performance of students members of the "experimental and control group" in the practice note card Teaching in favor of the post application of the experimental group, which outperformed the control group, and the results also found differences between the performance of students, members of the "experimental and control group", in the measure of selfefficacy in favor of the post application of the experimental group, which outperformed the control group.
\end{abstract}

Keywords: Micro-Teaching "Method - E-Learning Platforms- Pre-service Mathematics Teachers - Teaching practices-Self-efficacy.

\section{Introduction}

The rapid pace of change in the 21 st century requires individuals to have the flexibility to adapt to the complexity of those around them. Learning in this age means adapting to change. Individuals trying to adapt to this process must have the $21 \mathrm{st}$ century skills critical to maintaining self-development, and this goal can only be achieved through education. The learning process includes many elements such as students, curriculum, schools, and educational tools. Achieving targeted educational goals depends on organizing these elements together with the plan. Among these elements, the teacher factor is critical element in this process as they play an important role in acquiring expected behaviors from students. Emphasis must be placed on training qualified teachers to learn and teach how to learn because it is a very important goal for a qualified teacher in order to increase the educational quality of the nation at the required level. When considering this context, the most important factor is that the teacher must possess professional competence. A qualified teacher means that the generations they train become good individuals. However, 
the weaknesses in teacher education affects all generations and also decrease the quality of education.

For this purpose, one of the most important practices regarding the teaching profession in inservice training is activities that take place in the context of the Teaching practice course. "Teaching practice " is the first opportunity that provides "pre-service teachers "with an opportunity to practice the teaching knowledge and skills they have acquired in real classroom settings. However, activities in Teaching practice can be difficult and confusing for "preservice teachers "who have not had any experience before [1]. Moreover, "pre-service teachers "acquire a lot of professional or academic knowledge theoretically but they are not able to apply them in schools.

Not only do they know the content related to their teaching fields, but "pre-service teachers " must prepare for their profession by getting teaching roles. Observations and implementation in schools is a very important stage to raise awareness of pre - service teachers. However, it is not sufficient. For the purpose of this aim, it is necessary to plan the authentic Teaching practice that they can have teaching experiences. Therefore, micro-Teaching practice " is used to prepare "pre-service teachers "for the teaching profession by allowing them opportunities for teaching experiences and thus, an attempt is made developing a "Micro-Teaching "approach to meet the needs and cover problems encountered in teacher training programs [2]

Currently Pre-service teacher (PSTs) practice teaching by interacting in real-life situations that occur naturally in various school practices. These are not ideal contexts for novice teachers because they put beginners in situations with real students before demonstrating ability, notes are often not in the point of need and do not provide all students with similar experiences. The e-learning platforms and micro -teaching combine to provide a technological solution to bridge the gap between graduate preparation and real-world application. This study builds on Micro-Teaching Method Supported by ELearning Platforms - a combination of traditional micro-"Teaching practice "s and ELearning Platforms.

\section{Micro-Teaching Method}

The use of Micro-Teaching as an educational strategy dates back to the 1960s ,It is one of the recent innovations included in teacher education with a lot of positive aspects. Micro Teaching is one of the recent innovations in teacher education program which aims at modifying teachers behavior according to and impart the skills that need to be acquired by "pre-service teachers "to them [3]

Micro-Teaching is a training program that aims at simplifying the complexities From teaching operations[4].

Micro-Teaching approaches or strategies help create new and different opportunities for preservice teacher students about the form of planning, practice and much of the theoretical knowledge that they have learned and should be learned during their university studies[4]. the relationship between To apply theories. MicroTeaching is a method designed to provide and develop teaching skills for teachers and students at the university level [5] In summary, Micro-teaching is a way This is to provide student teacher expertise in a practice-based teaching environment[6].In another context Micro-Teaching has the following characteristics[6]:

- Micro-Teaching It provides a real learning environment by clearly defining the role of teacher and student..

- Reduces the complexity of the teaching process mode in real classrooms in terms of number, amount of time, and amount of learning contents.

- The training emphasizes mastering teaching activities such as skills, techniques, methods and curriculum selection.

- It provides better Control the form of practicing the educational activity because a lot can be easily manipulated to achieve this greater degree of control over the training program.

- Dimensions of the feedback is greatly expanded because a student can receive meaningful comments right after their 
performance, and with the help of a variety of technological teaching media in addition to monitoring and interaction analysis tools you can take the opportunity to improve their performance in the light of the comments provided. The essence of incorporating Micro-Teaching for the teacher education program is to enable the trainees to teach with each other for a shorter period of time so that they acquire some teaching skills before embarking on the actual Represent Teaching practice . Micro-Teaching is a process consisting of a set of stages: planning activities, teaching, Re-planning and teaching, criticism and re-criticism. The basic operations of this periodic process include a number of steps. First, the teacher in the pre-service stage prepares a special teaching plan (lesson plan) for the specific topic and submits the lesson to his/her instructor. Then he will teach for at least twenty minutes, and and this process is video-recorded. This video is shown in a form by the pre-service teacher in the presence of the teacher and colleagues, for the purpose of analyzing and evaluating the teacher's performance before service. And everyone should monitor the performance of the performers without any interruption during the presentation of the lessons, and take notes and errors that occur in them and correct them [7]. In line with the given feedbacks, the pre-service teacher revises his/her lesson plan and delivers his lesson again and the lesson is evaluated once more to determine the points at which the pre-service teacher is successful or unsuccessful. The results of this evaluation are shared with the preserve teacher; thus, the performance evaluation is completed ([8] .

Micro-Teaching is a form of application in which performance evaluations are performed on the basis of activities that take place with teaching skills, and during lesson delivery to a group of students. [9]. micro teaching as an excellent way to build skills and confidence, to experiment with a range of lecture / teaching styles To practice learning constructive feedback. [10]. Also, teaching here and applying it helps students teachers before service to develop awareness of classroom dynamics and pre-service teacher observation skills as well as their ability to observe what is classroom[10].

In this way, pre-service teacher students acquire many related knowledge, skills and experiences in the mini teaching. pre-service teachers in Micro-Teaching find more opportunities to develop performance and skills for preparation lesson plans, choose teaching goals that draw student attention, speak in front of the group, giving various examples ask questions, management classroom and effectively manage time and assessment techniques, Micro Teaching helps trainees get rid of fear of actual teaching[11]. categorically Recall that the teaching constitutes the following benefits for pre-service teachers[12]:

- exposed to the reality of teaching..

- provided for their roles as teachers.

- helps them realize the importance of planning, decision-making and implementing instructions.

- enables them to develop and improve teaching skills.

- helps them build their confidence in teaching.

Obviously, there are many benefits or advantages to teaching tutoring to trained teachers, especially When it is well planned and implemented. This is considered in Teaching practice it is expected that the student teachers or trained teachers will gain the following competencies[13]:-

- To acquire Teaching skills and the ability to deal with them in a practical way.

- That there be a change in focus and have a focal center in teaching and learning.

- To provide a change and improvement in the situation and dealing with teaching skills and styles.

- To enhance the practical application of teaching in measurable situations

\section{E-Learning Platforms}

The French Ministry of Education defines educational platforms as a comprehensive system that provides the user with a unified 
network access point for all tools, content and digital applications related to his activity [14].

E-learning platform: as a new educational product category, designed to serve as the primary educational environment in technologyintensive classrooms and it supports the teacher with tools for curriculum planning, class management, and student assessment, and is designed for classroom work Academic-led teacher as the primary carrier of the curriculum [15]

The functions of electronic educational platforms:

The educational platform has many functions due to the multiplicity of its electronic activities and services used in the educational process. the electronic educational platforms focus on the following functions [16]:-

- User management (log in with encryption)

- Educational content management (courses, content management, file management)

- Roles and rights with different rights

- Means of communication (chat and forums) and tools for learning (whiteboard, notebook, annotations, calendar, etc.)

- Display educational contents, courses, educational objects and media in a network compatible browser.

Benefits of electronic educational platforms in the educational process:

Benefits arising from the application of education using electronic educational platforms in British schools, which were conducted on (12) schools, where the project team was able to identify fourteen distinct key areas of benefits arising from the effective use of electronic educational platforms and related technologies, as follows[17]:-

1. The use of educational platforms has resulted in facilitating and developing the communication system between all those dealing with this platform, including teachers, students, and parents, in addition to school leaders.

2. Through this platform, parents are able to know how their children learn and monitor the children while they are at home.

3. Education across platforms increases the effectiveness of students and helps to develop the concept of continuing education and education outside of the classroom.

4. Facilitating the process of teachers obtaining educational resources, in addition to the large number of references that help teachers choose attractive and renewable references and methods of education.

5. The student through these platforms has a greater ability to learn by himself and assess his level of education.

6. Teachers can benefit from communicating with students and benefit from development according to the concept of feedback.

7. E-learning platforms have contributed to increased opportunities for collaborative education and interaction between teachers and schools; To gather resources and experiences, enhance cooperation between students, and increase interaction between all of these parties.

\section{Teaching practice}

The (NCTM) is one of the most international councils and organizations For this reason, the US National Council of Teachers of Mathematics (NCTM) has developed Principles to Actions: Ensuring Mathematical Success for All, These principles describe the conditions, structures, and policies that must exist for all students to learn. It addresses the basic elements of teaching and learning, equality, curriculum, tools and technology, and assessment. , Professionalism, and finally suggests special procedures for teachers to share the goal of ensuring sporting success for everyone [18].

Teaching effective mathematics is what makes the difference in students 'educational achievement and promotes the development of concepts in mathematics and has two main features: First, teachers and students must clearly define concepts, secondly, teachers must give students enough time to struggle with important mathematics, and the mathematics curriculum must follow These general recommendations for education are of high quality by encouraging students to explain problem solving and thinking [19]. 
Mathematics Teaching practice provide a framework to enhance mathematics education and learning, which are the basic teaching skills necessary to promote deep math learning. This framework provides teachers in schools with a common lens for collective action towards improving educational practices and supporting each other in possessing the necessary skills to teach in order to ensure successful math learning for all students, and reflect These practices are a set of educational strategies and curricula needed to foster deep learning of mathematics, and here are eight teaching It is a set of practices that support learning of mathematics [20]:

1) Establishing mathematical goals to focus on learning: in order for students to learn, and goals that fall within the learning progress, and uses goals to guide educational decisions.

2) Implementing tasks that enhance reasoning and problem solving: Effective teaching of mathematics helps students participate in solving and discussing tasks .

3) Use and connect mathematical representations: Effective teaching of mathematics helps students participate in making connections between mathematical representations to deepen understanding of mathematical concepts and procedures as tools to solve the problem [21]

4) Facilitate meaningful mathematical discourse: to build a common understanding of mathematical ideas through analyzing and comparing the student's way of thinking, and helps students engage in dialogue to advance mathematics learning for the whole class

5) Pose purposeful questions: purposeful questions to evaluate and develop thinking and encourage students to explain and think and build a sense about important mathematical ideas and relationships, as a fundamental component of meaningful mathematical dialogue[22].

6) Build procedural fluency from conceptual understanding: the student over time and becomes skilled in using flexible procedures because it helps him to solve mathematical problems, and procedural fluency is a skill used in performing mathematical operations and algebraic procedures Flexibility, accuracy and efficiency, which is an important component of mathematical competence. However, linking basic concept procedures is essential to building fluency.

7) Support productive struggle in learning mathematics: Effective teaching of mathematics helps students continue to progress individually and collectively while providing opportunities and support engaging in productive struggle for students to learn mathematics because it deals with mathematical ideas and relationships. Understanding the structure of mathematical problems and relationships between mathematical ideas, rather than simply seeking correct solutions, and focusing on challenging the student is a necessary component of education that supports students 'learning of mathematics (Hiebert \& Grouws,2007), and teaching that uses productive struggle yields long-term benefits, Students become more able to apply what they have learned to new situations and problems (Kapur, 2010), and in this direction the Chambers study (2016) emphasized the importance of productive struggle in creating strong learning experiences and effective teaching, and as Riser et al. , 2016) Also, the effectiveness of learning based on solving mathematical problems in promoting productive struggle and building key ideas, and the study indicated in this regard that the use of video-Based on Tasks It helps to support learning mathematics and improving practices

8) Elicit and use evidence of student thinking: using mathematics teaching to assess progress towards mathematical understanding and constantly modify teaching in ways that support and expand learning. Effective mathematics teaching evokes evidence of students 'current mathematic understanding and is used as a basis for educational decision-making. This interest points to the excitement and 
use of evidence as an essential component of formative assessment [23]

The need to direct students to use modern technologies to improve teaching performance, confirmed. Reliance on electronic platforms in learning mathematics for student teachers in the College of Education is a necessary tool to support Eeffective mathematics Teaching practice [24].

Both of these Teaching practice are based on more than improved learning activities and require skills and tools from the learner to employ them in the electronic platforms. The researcher has relied on a set of practices that are commensurate with the practices of NCTM, 2014 to achieve the goals of Micro-Teaching that are commensurate with the designed environment, namely[25]:

1. Teacher Clarity.

2. Electronic Discussion.

3. Collaborative learning.

4. Inquiry-based instruction.

5. Technology in the classroom.

6. Professional development.

7. Feedback.

8. Assessments.

\section{Self-efficacy}

People have little or no incentive to act if they do not believe they have the capabilities to achieve the desired results [26].Having selfefficacy about one's ability is important because it motivates one to succeed in life. Education researchers have conducted self- efficacy . studies on self-efficacy are based on Pandora theory. Pandora noted that while some individuals were adept at overcoming their phobia, other individuals with the same characteristics had difficulty defeating their phobia. It happens, it is observed that there are factors such as self-awareness and the belief that individuals desire to succeed [27]

The belief or perception that an individual has his or her abilities to carry out certain tasks motivates them. Self-efficacy means believing in one's capabilities[28]. self-efficacy as the conviction of an individual's ability to perform certain tasks in an appropriate and effective manner[29]. self-efficacy as an awareness of one's ability to perform at a certain in a task[30]
. self-efficacy is motivational, and social ability of individuals to use solutions successfully and responsibly in a variety of situations with the cognitive abilities and skills that individuals have acquired or learned to solve problems[31].

The teacher's self-efficacy is the teacher's personal beliefs in performing the necessary behaviors in order to successfully accomplish the task of teaching, including his ability to plan educational goals and implement them in mathematics successfully. This is the teacher's confidence in his ability to perform mathematics tasks. "pre-service teachers "with high levels of self-efficacy tend to be more motivating to learn from their peers and are likely to continue presenting challenges, The self-efficacy of mathematics for pre-services teacher differs. Teacher competency relates to teacher's professional knowledge and skills, while teacher self-efficacy is a broader concept. The teacher's self-efficacy goes beyond simply possessing professional knowledge and skills; It is also the belief that one has the ability to put his professional knowledge and skills into practice[32].

teacher's high self-efficacy him to successfully use his professional knowledge and skills, This means that low mathematics self-efficacy may prevent the use of professional knowledge and skills, which may adversely affect student learning[33]. Gavora stressed that the strong feature of self-regulation that enables teachers to use their potential to enhance students' understanding is the teacher's self-efficacy. Indeed, notes that a teacher's high self-efficacy enables him to successfully use his professional knowledge and skills. This means that low mathematics self-efficacy may prevent the use of professional knowledge and skills, which may adversely affect student learning[34]. the strong feature of self-regulation that enables teachers to use their potential to enhance students' understanding is the teacher's self-efficacy. Indeed [35] It must be recognized that a teacher's self-efficacy is linked to "persistence". The stronger self-efficacy, the greater perseverance - , and the more likely it is that teaching behaviors will succeed [36]. Teaching effectiveness is an important competence that 
affects teacher learning and the teaching process [37]. teaching effectiveness classify under three forms: teaching strategies, student participation, and classroom management. Teaching strategies include dimensions such as the teaching process, teaching methods, and creating student-friendly environments according to individual differences and assessment methods. Student participation is the teacher's effort to ensure that the student becomes active during and during the course. To this end, so the self-efficacy is important to teacher's ensure the active participation of the student. This is teachers positively affects the level of student achievement. The belief in self-efficacy in the light of classroom management plays a comprehensive role in controlling student behavior, ensuring students comply with the rules, conducting activities in the classroom smoothly, establishing an appropriate and effective classroom management system, and eliminating problems that may arise in the classroom[38].

This demonstrates how important self-efficacy is for a teacher, not only for the teacher himself but for students as well. Having a high sense of self-efficacy is the primary driver of the individual. Pandora as saying: Students with a high sense of self-efficacy show strong motivation and encounter difficulties as challenges to be mastered; Whereas students with a low sense of self-efficacy show weak commitment and approach difficulties such as threats and anxiety[39].

The aim of mathematics education is to impart mathematical knowledge and skills to students in the most effective and efficient way. Effective mathematics teaching depends on many factors such as students, teachers, programs, classroom climate, etc., and they are in fact the determinants of the quality of mathematics teaching. Rich mathematics knowledge is needed for effective mathematics teaching as teachers' beliefs on their competence influence student performance [40].

The most important programs in which teachers gain and develop proficiency in teaching mathematics are graduate preparation programs offered by colleges of education and the aim of these programs is to provide them with all the competencies and skills they need before graduation. Institutions that train teachers before service should give importance to practices and activities in teaching mathematics and the content of the course should relate to everyday life. In this context, Pre-service teacher may experience substantial changes in their selfefficacy beliefs and it is among the important topics in the literature because it is based on the effectiveness of teachers in teaching as it is defined as teachers' beliefs regarding their abilities to perform tasks related to teaching. Therefore, it appears that the period of Preservice teacher training plays an important role in the formation and maintenance of high selfefficacy beliefs for future teachers. To train teachers with high levels of self-efficacy, all factors affecting teacher competence must be taken into consideration and teacher training programs must be designed consecutively [41]. The teacher training process also includes a belief in self-efficacy. In the teacher education process, the self-efficacy of "pre-service teachers "must be developed alongside mathematical operations and problem-solving skills [42].

Some research on the education that preservice professors receive in undergraduate programs and their performance in the field provides information the information obtained in university study at the theoretical level, the training provided was insufficient, and it encountered difficulties in the implementation stages due to a lack of procedural knowledge [43]. Even if a pre-service teacher takes the course of Teaching practice, they believe that there are many shortcomings in applying Teaching practice and that there is no complementarity between practice and theory. Also, pre-service teachers feel incompetent, so the current research comes to bridge the gap between graduate preparation and real application using the platforms Micro-Teaching Method Supported by E-Learning Platforms.

Through the study, the researcher extracted a set of personality traits of high self-efficacy student teachers, namely[44]:- 
1) Participation of students in the implementation of activities.

2) Self-control in the positions of the raised discussions.

3) Self-confidence in terms of self-potential and information.

4) Provide continuous support to others.

5) Persuading others and communicating with them.

6) Attention to preparing the lesson.

7) Create a previous background to boot the topic.

8) Planning to improve the profession and performance.

9) Conversation with peers in groups on learning topics.

\section{Methodology}

Questions

The research is an attempt to answer the following major question:

What is the Effect of Micro-Teaching Method Supported by E-Learning Platforms in enriching Pre-service mathematics teacher students practices and improving self-efficacy? and improve Self-efficacy?

This question is subdivided into the following questions:

1. What is the Effect of Micro-Teaching Method Supported by E-Learning Platforms in enriching Pre-service Mathematics Teacher students Teaching practice?

2. What is the Effect of Micro-Teaching Method Supported by E-Learning Platforms in improve Pre-service mathematics teacher students' Selfefficacy?

\section{Objectives}

The present research aims at:

1. Exploring the Effect of Micro-Teaching Method Supported by E-Learning Platforms in enriching Pre-service Mathematics Teacher students Teaching practice .

2. Exploring the Effect of Micro-Teaching Method Supported by E-Learning Platforms in improve Pre-service students Mathematics Teachers' Teachers' Self-efficacy.

\section{Significance}

1. Provide a technological solution to bridge the gap between graduate preparation and real-world application for Teaching practice It is a response to the recent trends in the field of information and communication technology and its applications in the field of education

2. Will provide a scientific basis based on research preparation of mathematics to use Micro-Teaching Method Supported by ELearning Platforms

3. Directed towards the use of E-Learning Platforms in education, especially in lifelong learning, as a fertile ground for investment and global competition, and to benefit from the demand of millions of learners to use the Internet

4. It may draw attention to effective mathematics Teaching practice .

5. The need for the educational field to a new type of learning fits the orientation of the 21 st century students and their attitudes.

6. By focusing on the importance of Microteaching, researchers in the field of education undertake further research on other aspects of this subject.

7. To direct the attention of researchers to conduct further research on the Self-efficacy.

\section{Hypotheses}

1. There are no statistically A big difference in the average score groups at the level $(\alpha<0.05)$ in Teaching practice observation.

2. There is no statistically significant difference in the mean scores of the "experimental and control group"s at the level $(\alpha<0.05)$ on the self-efficacy scale.

3. There is no correlation between the students of the experimental group and the control group level $(\alpha<0.05)$ in Teaching practice observation and selfefficacy scale.

\section{Instructional design}

Use the following steps to ensure that you use instructional design to Effect of MicroTeaching Method Supported by E-Learning 
Platforms in enriching Pre-service Mathematics Teachers' Teaching practice and improve Selfefficacy, The current research relied on the following steps in designing the educational platform:

1) Preparing the platform.

2) Scenario design for educational content.

3) Upload content.

4) Register students to $\log$ in to the platform.

5) Distribute roles to students.

6) Use your teaching strategy.

7) Procedure formative and final evaluation

\section{Research Design}

The present research aims at measuring the Effect of Micro-Teaching Method Supported by E-Learning Platforms on Pre-service Mathematics Teacher students/Teaching practice "s and self-efficacy. Thus, the author adopted the quasi-experimental design for designing two groups, experimental and control with pre-and post-measures, where the experimental group was taught through Micro-Teaching Method Supported by E-Learning Platforms, while the control group was taught in the traditional teaching method. Both classes used the same teaching content and were taught by the same teacher. Two tools were applied in this research: Teaching practice observation and Self-Efficacy Scale.

\section{Study Population}

The population of the research consisted of (113) all the second year of Pre-service mathematics teachers who were enrolled mathematics teacher education programmer in the College of Education at Tanta University, In the second semester of the academic year 2019/2020.

\section{Study Sample}

The pre-service mathematics teachers who participated in the research consisted of two equivalent groups, the experimental group consisted of (30) and control group consisted of (30), who were randomly selected after adopting the variables and making sure that the two groups are equivalent.

\section{Tools}

In order to achieve the objectives of the research and answer its questions, a Teaching practice observation and a scale of self-efficacy were prepared.

\section{Teaching Practice Observation:}

The Validity of ( Teaching practice observation):

The validity of the arbitrators: The researcher presented the note card in its initial form to a group of specialists in curricula, teaching methods and educational technology. In order to express an opinion on the suitability of the dimensions of the measurement subject, the note card became in its final form, after making adjustments to the referees, consisting of (42) statements. The subjects respond to the terms of the scale through their responses.

\section{Reliability of the Teaching practices observation:}

In order to measure the degree of the reliability of the tool, Cronbach's Alpha $(\alpha)$ was used to verify the tool's reliability. The equation was applied to the pilot sample and it showed that the scale's reliability coefficient is high rated (0.873) which indicates that the observation is highly reliable and could be reliable in the field application of the Study.

The internal consistency of the Teaching practice observation Scale was verified through the application of the observation to the pilot sample, by calculating the correlation coefficients between the score on each of the scale paragraphs and the total score of the scale, and the following results obtained by the researcher:-

Table (1) Correlation coefficients for the fields of Teaching practice

\begin{tabular}{|l|l|}
\hline \multicolumn{1}{|c|}{ Dimensions } & $\begin{array}{l}\text { Correlation } \\
\text { coefficient }\end{array}$ \\
\hline 1. Teacher Clarity. & $0.846^{* *}$ \\
\hline 2. Electronic Discussion. & $0.832^{* *}$ \\
\hline 3. Collaborative learning. & $0.723 * *$ \\
\hline 4. Inquiry-based instruction. & $0.771^{* *}$ \\
\hline 5. Technology in the classroom. & $0.882^{* *}$ \\
\hline 6. Professional development. & $0.854^{* *}$ \\
\hline 7. Feedback. & $0.771 * *$ \\
\hline 8. Assessments. & $0.752 * *$ \\
\hline Total & $0.843 * *$ \\
\hline
\end{tabular}

The Validity of (Self-Efficacy Scale):

The purpose of the scale: Measuring the selfefficacy of the student teachers in the College of Education: which the researcher defined as: the 
power or desire that drives the student's behavior and directs it towards achieving the educational goals in the mini-teaching course:-

- The researcher conducted an exploratory study on a sample of the same age group used in the experimental treatment. The researcher sought to verify the respondents 'acceptance of the tools used to collect the research data, and to verify the clarity of the scale phrases.

- Developing the instructions for applying the scale, the researcher formulated the scale instructions in a clear, understandable and direct way.

- The researcher prepared the scale for arbitration, and then presented it to arbitrators from professors of mental health, psychology, curricula and teaching methods, and based on the results of the arbitration, the expressions that obtained less than $80 \%$ approval were excluded, and the wording of some phrases was modified according to the opinions of the arbitrators. With this, the scale settled in its initial form on (47), and the researcher relied on this gradation (typical, good, and weak) so the student's answer would be given the next score if the statement was positive $(1,2,3)$ and vice versa in the case of the statement in negative direction $(3,2,1)$

- After excluding the phrases in the light of the opinions of the arbitrators, the scale became (45) statements.

\section{First: Verify the scale}

a. The validity of the arbitrators: The researcher presented the scale in its initial form to a group of specialists in mental health, psychology, curricula and teaching methods. This is to express an opinion on the appropriateness of the dimensions of the measurement. The researcher retained the expressions whose validity was agreed upon by the arbitrators by $80 \%$ or more and after making the amendments referred to by the referees, which included an amendment in the formulation of some paragraphs of the scale, so the scale became in its final form after the procedure. Modifications of the referees consist of (45) statements, the respondents respond to the scale phrases through its responses.

\section{Reliability of the Self-Efficacy Scale:}

In order to measure the degree of the reliability of the tool, Cronbach's Alpha $(\alpha)$ was used to verify the tool's reliability. The equation was applied to the pilot sample and it showed that the scale's reliability coefficient is high rated (0.864) which indicates that the scale is highly reliable and could be reliable in the field application of the research.

The internal consistency of the Self-Efficiency Scale was verified through the application of the scale to the pilot sample, by calculating the correlation coefficients between the score on each of the scale paragraphs and the total score of the scale, and the following are the results obtained by the researcher:-

Table (2) Correlation coefficients for the fields of
Teaching practice
\begin{tabular}{|l|c|}
\hline \multicolumn{1}{|c|}{ Dimensions } & $\begin{array}{c}\text { Correlati } \\
\text { on } \\
\text { coefficien } \\
\text { t }\end{array}$ \\
\hline $\begin{array}{l}\text { Participation of students in the } \\
\text { implementation of activities. }\end{array}$ & $0.782^{* *}$ \\
\hline $\begin{array}{l}\text { Self-control in the positions of the raised } \\
\text { discussions. }\end{array}$ & $0.883^{* *}$ \\
\hline $\begin{array}{l}\text { Self-confidence in terms of self-potential } \\
\text { and information. }\end{array}$ & $0.572^{* *}$ \\
\hline Provide continuous support to others. & $0.776^{* *}$ \\
\hline $\begin{array}{l}\text { Persuading others and communicating } \\
\text { with them. }\end{array}$ & $0.851^{* *}$ \\
\hline $\begin{array}{l}\text { Attention to preparing the lesson. } \\
\text { Create a previous background to boot } \\
\text { the topic. }\end{array}$ & $0.842^{* *}$ \\
\hline $\begin{array}{l}\text { Planning to improve the profession and } \\
\text { performance. }\end{array}$ & $0.768^{* *}$ \\
\hline $\begin{array}{l}\text { Conversation with peers in groups on } \\
\text { learning topics. }\end{array}$ & $0.833^{* *}$ \\
\hline
\end{tabular}

\section{Results And Discussion}

1) The First Hypothesis: There are no statistically significant differences in the mean scores of the "experimental and control group"s at the level $(\alpha<0.05)$ in Teaching practice observation.

2) In order to verify hypothesis no (1), Independent Sample T-test was used. The results are presented in the following table:- 
Table (3) The significance of the difference between the mean scores of the post Teaching practice observation of the "experimental and control groups In the post application.

\begin{tabular}{|c|c|c|c|c|c|c|c|}
\hline \multirow{2}{*}{ Dimensions } & \\
\hline & Groups & $\mathrm{N}$ & Mean & SD & "T" & DF & Sig \\
\hline \multirow{2}{*}{$\begin{array}{l}\text { Teacher } \\
\text { Clarity. }\end{array}$} & Control & 30 & 9.83 & 0.75 & \multirow{2}{*}{28.11} & \multirow{2}{*}{58} & \multirow{2}{*}{0.01} \\
\hline & experimental & 30 & 14.47 & 0.51 & & & \\
\hline \multirow{2}{*}{$\begin{array}{l}\text { Electronic } \\
\text { Discussion. }\end{array}$} & Control & 30 & 11.87 & 0.35 & \multirow{2}{*}{27.03} & \multirow{2}{*}{58} & \multirow{2}{*}{0.01} \\
\hline & experimental & 30 & 16.43 & 0.86 & & & \\
\hline \multirow{2}{*}{$\begin{array}{l}\text { Collaborative } \\
\text { learning. }\end{array}$} & Control & 30 & 10.77 & 0.82 & \multirow{2}{*}{28.37} & \multirow{2}{*}{58} & \multirow{2}{*}{0.01} \\
\hline & experimental & 30 & 15.00 & 0.00 & & & \\
\hline \multirow{2}{*}{$\begin{array}{l}\text { Inquiry-based } \\
\text { instruction. }\end{array}$} & Control & 30 & 11.87 & 0.35 & \multirow{2}{*}{16.93} & \multirow{2}{*}{58} & \multirow{2}{*}{0.01} \\
\hline & experimental & 30 & 14.60 & 0.81 & & & \\
\hline \multirow{2}{*}{$\begin{array}{l}\text { Technology } \\
\text { in the } \\
\text { classroom. }\end{array}$} & Control & 30 & 11.77 & 0.43 & \multirow[t]{2}{*}{42.97} & \multirow{2}{*}{58} & \multirow{2}{*}{0.01} \\
\hline & experimental & 30 & 17.07 & 0.52 & & & \\
\hline \multirow{2}{*}{$\begin{array}{l}\text { Professional } \\
\text { development. }\end{array}$} & Control & 30 & 11.07 & 0.45 & \multirow{2}{*}{25.68} & \multirow{2}{*}{58} & \multirow{2}{*}{0.01} \\
\hline & experimental & 30 & 14.23 & 0.50 & & & \\
\hline \multirow[t]{2}{*}{ Feedback. } & Control & 30 & 10.90 & 0.31 & \multirow[t]{2}{*}{33.43} & \multirow{2}{*}{58} & \multirow{2}{*}{0.01} \\
\hline & experimental & 30 & 14.30 & 0.47 & & & \\
\hline \multirow[t]{2}{*}{ Assessments. } & Control & 30 & 11.30 & 0.53 & \multirow[t]{2}{*}{19.28} & \multirow{2}{*}{58} & \multirow{2}{*}{0.01} \\
\hline & experimental & 30 & 14.60 & 0.77 & & & \\
\hline \multirow[t]{2}{*}{ Total } & Control & 30 & 89.37 & 1.35 & 79.46 & & \\
\hline & experimental & 30 & 120.7 & 1.68 & & 58 & 0.01 \\
\hline
\end{tabular}

Table(3) shows statistically significant differences at the significant level $(0.01)$ between the post means of the Teaching practice observation scores of the Control and experimental group in favor of the post test. This confirmed the effectiveness of using the MicroTeaching Method Supported by E-Learning Platforms.

Table (4) Paired Sample T-test of the significance of the difference between the mean scores of the pre and post Teaching practice observation of the experimental students $(\mathrm{N}=30)$

\begin{tabular}{l|c|c|c|c|c|c|c}
\hline \multirow{2}{*}{ Domains } & \multicolumn{2}{|c|}{ Pre } & \multicolumn{2}{|c|}{ Post } & \multirow{2}{*}{ T } & DF & Sig \\
\cline { 2 - 5 } & Mean & SD & Mean & SD & T \\
\hline Teacher Clarity. & 5.43 & 0.68 & 14.47 & 0.51 & 49.51 & 29 & 0.01 \\
\hline $\begin{array}{l}\text { Electronic } \\
\text { Discussion. }\end{array}$ & 5.40 & 0.77 & 16.43 & 0.86 & 48.53 & 29 & 0.01 \\
\hline $\begin{array}{l}\text { Collaborative } \\
\text { learning. }\end{array}$ & 5.20 & 0.55 & 15.00 & 0.00 & 97.44 & 29 & 0.01 \\
\hline $\begin{array}{l}\text { Inquiry-based } \\
\text { instruction. }\end{array}$ & 5.27 & 0.58 & 14.60 & 0.81 & 51.42 & 29 & 0.01 \\
\hline $\begin{array}{l}\text { Technology in } \\
\text { the classroom. }\end{array}$ & 5.30 & 0.70 & 17.07 & 0.52 & 78.87 & 29 & 0.01 \\
\hline $\begin{array}{l}\text { Professional } \\
\text { development. }\end{array}$ & 5.33 & 0.66 & 14.23 & 0.50 & 52.82 & 29 & 0.01 \\
\hline
\end{tabular}

\begin{tabular}{l|c|c|c|c|c|c|c}
\hline Feedback. & 5.20 & 0.55 & 14.30 & 0.47 & 75.32 & 29 & 0.01 \\
\hline Assessments. & 5.43 & 0.77 & 14.60 & 0.77 & 50.95 & 29 & 0.01 \\
\hline Total & 42.57 & 2.10 & 120.70 & 1.68 & 143.07 & 29 & 0.01 \\
\hline
\end{tabular}

2) The Second Hypothesis: There is no statistically significant difference in the mean scores of the "experimental and control group's at the level $(\alpha<0.05)$ on the self-efficacy scale.

In order to identify if there are statistically significant differences in the mean scores of the "experimental and control groups in the self-efficacy scale, Independent Sample Ttest was utilized, as shown in table (5)

Table (5) The significance of the differences between the mean scores of the post self-efficacy scale of the "experimental and control group's

\begin{tabular}{|c|c|c|c|c|c|c|c|}
\hline Dimensions & Groups & $\mathrm{N}$ & Mean & S D & $\mathrm{T}$ & DF & Sig \\
\hline \multirow{2}{*}{$\begin{array}{l}\text { Participation of } \\
\text { students in the } \\
\text { implementation } \\
\text { of activities. }\end{array}$} & Control & 30 & 11.33 & 1.15 & \multirow[b]{2}{*}{10.49} & \multirow[b]{2}{*}{58} & \multirow{2}{*}{0.01} \\
\hline & experimental & 30 & 14.03 & 0.81 & & & \\
\hline \multirow{2}{*}{$\begin{array}{l}\text { Self-control in } \\
\text { the positions of } \\
\text { the raised } \\
\text { discussions. }\end{array}$} & Control & 30 & 11.57 & 1.01 & \multirow[b]{2}{*}{7.45} & \multirow[b]{2}{*}{58} & \\
\hline & experimental & 30 & 13.07 & 0.45 & & & 0.01 \\
\hline \multirow{2}{*}{$\begin{array}{l}\text { Self- } \\
\text { confidence in } \\
\text { terms of self- } \\
\text { potential and } \\
\text { information. }\end{array}$} & Control & 30 & 11.43 & 1.07 & \multirow[b]{2}{*}{12.74} & \multirow[b]{2}{*}{58} & \\
\hline & experimental & 30 & 14.67 & 0.88 & & & 0.01 \\
\hline \multirow{2}{*}{$\begin{array}{l}\text { Provide } \\
\text { continuous } \\
\text { support to } \\
\text { others. }\end{array}$} & Control & 30 & 11.27 & 0.98 & \multirow[b]{2}{*}{14.33} & \multirow[b]{2}{*}{58} & \\
\hline & experimental & 30 & 14.60 & 0.81 & & & 0.01 \\
\hline \multirow{2}{*}{$\begin{array}{c}\text { Persuading } \\
\text { others and } \\
\text { communicating } \\
\text { with them. }\end{array}$} & Control & 30 & 11.53 & 1.07 & \multirow{2}{*}{11.67} & \multirow{2}{*}{58} & \\
\hline & experimental & 30 & 14.47 & 0.86 & & & 0.01 \\
\hline \multirow{2}{*}{$\begin{array}{l}\text { Attention to } \\
\text { preparing the } \\
\text { lesson. }\end{array}$} & Control & 30 & 11.17 & 1.56 & \multirow{2}{*}{9.74} & \multirow{2}{*}{58} & \\
\hline & experimental & 30 & 14.10 & 0.55 & & & 0.01 \\
\hline \multirow{2}{*}{$\begin{array}{c}\text { Create a } \\
\text { previous } \\
\text { background to } \\
\text { boot the topic. }\end{array}$} & Control & 30 & 11.00 & 1.36 & \multirow[b]{2}{*}{11.03} & \multirow[b]{2}{*}{58} & \\
\hline & experimental & 30 & 14.10 & 0.71 & & & 0.01 \\
\hline \multirow{2}{*}{$\begin{array}{l}\text { Planning to } \\
\text { improve the } \\
\text { profession and } \\
\text { performance. }\end{array}$} & Control & 30 & 11.17 & 1.32 & \multirow[b]{2}{*}{8.15} & \multirow[b]{2}{*}{58} & \\
\hline & experimental & 30 & 13.93 & 1.31 & & & 0.01 \\
\hline \multirow{2}{*}{$\begin{array}{l}\text { Conversation } \\
\text { with peers in } \\
\text { groups on } \\
\text { learning topics. }\end{array}$} & Control & 30 & 11.47 & 0.90 & \multirow[b]{2}{*}{10.72} & \multirow[b]{2}{*}{58} & \\
\hline & experimental & 30 & 14.27 & 1.11 & & & 0.01 \\
\hline \multirow{2}{*}{ Total } & Control & 30 & 101.93 & 4.12 & \multirow{2}{*}{12.03} & \multirow{2}{*}{58} & \\
\hline & experimental & 30 & 112.97 & 2.87 & & & 0.01 \\
\hline
\end{tabular}


Table 3 showed statistically significant differences at the significant level (0.01) between the mean responses of the post selfefficacy scale of the "experimental and control group"s in favor of the experimental group who was taught through the Micro-Teaching Method Supported by E-Learning Platforms. The result confirmed that this strategy helps students think creatively and reinforces cognitive development and meta-cognition by providing several opportunities of communication between learners.

- The Third Hypothesis: There is no correlation between the students of the experimental group and the control group at the significant level $(\alpha<0.05)$ in Teaching practice observation and self-efficacy scale.

Pearson Correlation Coefficient was utilized to explain the significance of relation between the two variables, as shown in Table (6):

Table (6) The significance of the differences between the mean scores of the post self-efficacy scale of the "experimental and control group's

\begin{tabular}{|l|c|c|}
\hline \multirow{2}{*}{$\begin{array}{l}\text { Attitudes } \\
\text { towards } \\
\text { the self- } \\
\text { efficacy } \\
\text { scale }\end{array}$} & \multicolumn{2}{|c|}{ Teaching practice } \\
\cline { 2 - 3 } & $\begin{array}{l}\text { Correlation } \\
\text { Coefficient }\end{array}$ & Sig \\
\cline { 2 - 3 } & 0.632 & 0.01 \\
\hline
\end{tabular}

Table(6) illustrated that there is statistically significant correlation (positive) at the level of (0.01) between the Teaching practice of the students of College of Education, after using the Micro-Teaching Method Supported by ELearning Platforms, and their attitudes towards the self-efficacy scale. This indicates that the more scores the students get in Teaching practice observation, the more self-efficacy they have.

\section{Recommendations}

Micro teaching must be preserved in undergraduate teacher education programs because of its contributions to improving teaching skills, confidence, low level of anxiety and fear, the ability to manage classes, choosing appropriate teaching goals, preparing a good lesson plan, and the ability to speak in front of the group as well as choosing The right educational materials and the right time management.

This research recommends the following:

1. Applying the E-Learning Platforms to all the courses taught in

2. Preparing university programs and study based on applying E-Learning Platforms in university education.

3. The need of transforming traditional curricula to E-Learning Platforms in order to well prepare the students.

4. Using electronic learning technology more widely.

5. Training students on employing some thinking skills which would help them in the real application in real life.

6. The need of conducting further studies on ELearning Platforms

\section{Conclusion}

The current research proposes conducting similar studies in the field of teaching mathematics, and using educational platforms supported by various technologies to, identify their impact on mathematical variables such as mathematical reasoning and mathematics practices in the light of (Nctm) standards, as well as employing internet technologies in identifying students' trends and perseverance in working in electronic environments and conducting deep discussions to reach deep learning by relying on electronic analysis programs for students' performance.

\section{References}

[1] Aggarawal, J. C. (2006). Principles, Methods and Techniques of Teaching. Second Revised Edition. New Delhi: VIKAS Publishing House PVT Ltd.

[2] Allen, D. W. (1967).Micro-teaching: A description.California: TeacherEducation Program, Standford University.

[3] Amobi, A. A. (2005). Preservice teachers' reflectivity on the sequence and consequences of teaching actions in a microteaching experience.Teacher Education Quarterly, 32(1), 115-130.

[4] Benton-Kupper, J. (2001). The Microteaching Experience: Student Perspectives. Education, 121(4), 830-835. 
[5] Bozkurt, I. (2012). A comparison of elementary teachers' and teacher candidates' perceptions of their proficiency in teaching mathematics. (Unpublished Master Thesis). Erzincan University Primary mathematics Education, Erzincan.

[6] Brown, G. (1975). Microteaching a Program of Teaching Skills. Methaun: London.

[7] Chris Dede, John Richards(2012) Digital Teaching Platforms: Customizing Classroom Learning for Each Student Kindle Edition, Teachers College, Columbia University.

[8] Clymer, J. B., \& Wiliam, D. (2006/2007). Improving the way we grade science. Educational Leadership, 64(4), 36-42.

[9] El-ahwal, M., Shahin, A. (2020). Using videoBased on Tasks for Improving Mathematical Practice and supporting the productive struggle in Learning Math among Student Teachers in the Faculty of Education. International Journal of Instructional Technology and Educational Studies, 1(1), 26-31. doi: 10.21608/ihites.2020.29051.1013

[10] Fuson, K. C., Kalchman, M., \& Bransford, J. D. (2005). Mathematical Understanding: An Introduction. In M. S. Donovan, \& J. Bransford (Eds.), How Students Learn Mathematics in the Classroom (pp. 217-256). Washington DC: National Research Council.

[11] Gavora P, (2010). Slovak Pre-service Teacher Self-efficacy: Theoretical and Research Considerations. The New Educational Review, 21(2): 17-30.

[12] Güney, K. \& Semerci, Ç. (2009). Mikro-Yansıtıcı Öğretim Yönteminin Öğretmen Adaylarının Yansıtıcı Düşünmesine Etkisi. [The Effect of Micro-Reflective Teaching Method in Accordance with the Reflective Thinking Activities of Students Teachers]. Doğu Anadolu Bölgesi Araştırmaları, 8(1), 77-83.

[13] Gürbüz, F.(2015). The V1ews of Pre-Service Teachers Who Take Special Teaching Course within the Context of Pedagogical Formation Certıficate Program about Micro-Teaching Method and a Physics Lesson Plan. International Journal on New Trends in Education and Their Implications, 6(4), 17.

[14] Han, Mark, Yu, \& Zeng(2015) Self-efficacy and Attitudes Towards Mathematicsof Undergraduates:A U.S. andTaiwan Comparison, Journal of Mathematics Education, Vol. 8, No. 1, pp. 1-15.

[15] Hiebert, J.,\& Grouws, D. A. (2007). The effects of classroom mathematics teaching on students' learning. In F. Lester (Ed.), Second handbookof research on mathematics teaching and learning (pp. 371-404). Charlotte, NC: Information Age.

[16] Homanova, Zuzana, Prextova, Tatiana (2017) "Educational Networking Platforms Through the Eyes of Czech Primary School Students" Academic Conferences International Limited, European Conference on e-Learning; Kidmore End: 195-204.

[17] Inel Ekici, Didem(2018) Development of PreService Teachers' Teaching Self-Efficacy Beliefs through an Online Community of Practice, Asia Pacific Education Review, v19 n1 p27-40 Mar .

[18] Jewitt, C., Hadjithoma-Garstka, C., Clark. W, Banaji, S. and Selwyn, N. (2010) School use of Learning Platforms and associated technologies: final project report, Coventy, Becta. (1) (PDF) The use of learning platforms to organise learning in English primary and secondary schools.

[19] Kaçar, T. (2016). Analyzing of self-efficacy beliefs of elemantary school teachers. (Unpublished Master Thesis). Dokuz EylülUniversity Educational Sciences Institution, İzmir.

[20] Kapur, M. (2010). Productive failure in mathematical problem solving.Instructional Science, 38(6), 523-550.

[21] Kartal, H. (2018). Factors Affecting preservice primary teachers' attitudes towards primary read and write teaching. Kastamonu Education Journal, 26(2), 509-521. doi:10.24106/kefdergi.389814.

[22] Kavas, G.(2009). Video Destekli Web TabanliAkran Degerlendirme Sisteminin Mikroogretim UygulamalariUzerine Etkileri: Bilgisayar Ogretmenligi Adayları Ornegi(Yuksek Lisans Tezi). T.C.Marmara Universitesi Egitim Bilimleri Enstitusu, Bilgisayar ve Ogretim Teknolojileri Ana Bilim Dali, Bilgisayar ve Ogretim Teknolojileri Ogretmenligi Bilim Dali.

[23] Kpanja, E. (2001). A study of the effects of video tape recording in microteaching training. British Journal of Educational Technology, 32(4), 483-486.

[24] Kuran, K. (2009). Mikro Öğretimim Öğretmenlik Meslek Bilgi ve Becerilerinin Kazanilmasina Etkisi. [The Effect of Micro Teaching on Teachers' Gaining of Knowledge and Skills]. Mustafa Kemal Üniversitesi Sosyal Bilimler Enstitüsü Dergisi, 6(11), 384-401 
[25] Mahmud, I., \& Rawshon, S. (2013).Micro teaching to improve teaching method:An analysis on students' perspectives.IOSR Journal of Research \& Methodin Education (IOSRJRME)., 1(4), 2320-7388, 69-76.

[26] Mahuta, M. G. (2009). An Introduction to the Teaching Profession for Teacher-Trainees. Sokoto: Mathi Publishers.

[27] Michael Piotrowski (2009) What is an ELearning Platform?, In book: Learning Management System Technologies and Software Solutions for Online Teaching: Tools and Applications, Publisher: IGI Global, Editors: Kats, Yefim. DOI: 10.4018/978-161520-853-1.ch002

[28] Moschkovich, J. N. (2012).Mathematics, the Common Core, and language: Recommendations for mathematics instruction for ELLs aligned with the Common Core. Proceedings of the Un-derstanding Language conference. Stanford, CA: Stanford University.

[29] National Council of Teachers of Mathematics (2014) Principles to Actions: Ensuring Mathematical Success for All.Reston, VA.

[30] National Council of Teachers of Mathematics. (2000). Principles and standards for school mathematics. Reston, VA: Author.

[31] Peker, M. (2009). Pre-Service Mathematics Teacher Perspectives about the Expanded Microteaching Experiences. Journal of Turkish Educational Sciences, 7(2): 353-376.

[32] Riser, S. C., et al. (2016), Fifteen years of ocean observations with the global Argo array, Nature Climate Change, 6(2), 145-153, doi:10.1038/nclimate2872.

[33] Saban, A. \& Coklar, A. N. (2013). Pre-Service Micro -Teaching Method in Teaching Practice Classes. 12i2/12221.pdf

[34] Sakız, G. (2013). Key word in success: Selfefficacy. Journal of Uludag University Faculty of Education, 26 (1), 185-209.

[35] Shahin, A. (2020). Employing infographics based on tablet applications to improve professional competence in the light of the digital transformation of education technology specialists. International Journal of Instructional Technology and Educational Studies, 1(1), 23-25. doi: 10.21608/ihites.2020.28769.1006.

[36] sher, E., \& Pajares, F. (2009). Sources of SelfEfficacy in Mathematics A Validation Study. Contemporary Educational Psychology, 34, 89101
[37] Sonmez, D. (2012). Affects of Microteaching Course on Student Teaching Practice.

[38] Subramaniam, K. (2006). Creating a Microteaching evaluation form: The needed evaluation criteria. Education, 126(4), 666-677.

[39] Turhan, H.S. (2008). Examining the opinions of primary school 4 and 5th grade teachers about teaching mathematics course in terms of some variables (Unpublished Master Thesis). Gazi University, Social Sciences Institution, Ankara.

[40] Undiyaundeye, F. \& Inakwu, A. A. (2013). Micro-Teaching Experiences in Pre-Service Education Programme.

[41] Ural, A. (2015). The Effect of mathematics selfefficacy on anxiety of teaching mathematics. Journal of Theoritical Educational Sciences, 8(2), 173-184. Doi:10.5578/keg.9075 .

[42] Wastiau, P. (2010). Virtual Learning Platforms in Europe: What can we learn from experience in Denmark, the United Kingdom and Spain? A Comparative Overview. Brussels: European Schoolnet \& Paris.

[43] Weinert, A.B. (2001). Psychology of career development. International Encyclopedia of the Social and Behavioral Sciences, Elsevier Science, 1471-1476.

[44] Yıldırım, N. \& Demirtaş, Z. (2008). Student views based a proposal for first reading and writing teaching course of classroom teaching department. Gaziantep University Journal of Social Sciences, 9(3), 681-695.

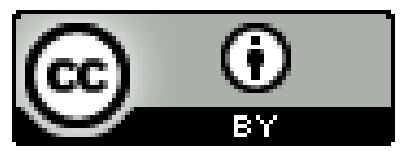

